IMAGENS

\title{
Corpos em equilíbrio: imagens e cotidiano ribeirinho no porto do Açaí e na ilha do Maracujá, Belém (PA)
}

\author{
Bodies in balance: riverside images and \\ everyday life in Açaí Port and on Maracujá Island, \\ Belém (State of Pará)
}

\author{
Flávio Leonel Abreu \\ da Silveira \\ Professor adjunto do Laboratório \\ de Antropologia Arthur Napoleão \\ Figueiredo/Universidade Federal do \\ Pará (UFPA). \\ Av. 25 de setembro, 1848/102B \\ 66093-005 - Belém - PA - Brasil \\ flabreu@ufpa.br
}

\section{Terezinha de Fátima Ribeiro Bassalo \\ Mestranda do Programa de Pós-graduação em Ciências Sociais/ UFPA. \\ Travessa Francisco Monteiro, 195 66070-190 - Belém - PA - Brasil \\ terribeiro3@gmail.com}

SILVEIRA, Flávio Leonel Abreu da; BASSALO, Terezinha de Fátima Ribeiro. Corpos em equilíbrio: imagens e cotidiano ribeirinho no porto do Açaí e na ilha do Maracujá, Belém (PA). História, Ciências, Saúde Manguinhos, Rio de Janeiro, v.19, n.3, jul.-set. 2012, p.1049-1073.

\section{Resumo}

Refletir, partindo do registro fotográfico, sobre o fluxo de ida e volta dos moradores da ilha do Maracujá, entre a ilha e Belém, fazendo uso das formas com que utilizam seus corpos ou 'sabem servir-se' deles, no que Mauss chamou de técnicas corporais. Corpos evidenciados, uma vez que estão sempre à mostra, capazes, portanto, de ser visualmente etnografados. Inspirado em Certeau, o artigo busca pensar as táticas corporais elaboradas pelos moradores da ilha ao praticar as paisagens de pertença, revelando expressões de corpo peculiares na construção de suas experiências cotidianas. Tais observações não remetem a um corpoobjeto, mas a um corpo que é o sujeito da cultura, como diz Csordas, um corpo que é "a base existencial da cultura".

Palavras-chave: corpo; ribeirinhos; insularidade; Amazônia.

\section{Abstract}

Based on photographic records, this paper reflects on the ebb and flow of the Maracujá Island dwellers, between the island and Belém, making use of the ways they use their bodies or 'know how to use' them, that Mauss called corporal techniques. Bodies disclosed, since they are always exposed and therefore capable of being visually and ethnographically categorized. Inspired on Certeau, the article seeks to think of the corporal tactics devised by island residents to practice the landscapes of belonging revealing peculiar body expressions in constructing their everyday experiences. Such observations do not refer to a body-object, but to a body that is the subject of culture, as Csordas says, a body that is "the existential basis of culture".

Keywords: body; riverside dwellers; island mentality; Amazônia. 
$\mathrm{H}^{a}$ á uma longa tradição francesa nas ciências humanas voltada às discussões sobre o corpo e os seus usos pelos diversos grupos humanos, remontando aos estudos clássicos de Robert Hertz sobre a preeminência da mão direita (escrito em 1909), passando por Marcel Mauss - estudos que datam de 1934 - acerca das 'técnicas corporais', alcançando as reflexões de André Leroi-Gourhan $(1987,1990)$ sobre as relações entre o gesto e a técnica, uma vez que o autor reflete a respeito das relações entre o corpo e o uso de ferramentas na configuração da 'ação técnica', a fim de pensar as complexas interações entre forma e conteúdo, tanto dos artefatos construídos pelo homem quanto dos demais construtos em consonância com o gesto técnico.

Segundo Leroi-Gourhan (1987, p.34), a "associação operatória do utensílio e do gesto ... pressupõe a existência de uma memória na qual se inscreve o programa do com-portamento", portanto, as "possibilidades gestuais" do "sujeito étnico" integrariam o corpo - a primeira ferramenta do homem, como indicou Mauss - ao utensílio, engendrando singularidades comportamentais humanas dadas na experiência do gesto, que, con-sequentemente, estão ligadas à elaboração concomitante de imagens mentais e à liberação da memória no seio do 'corpo social' (para usar uma imagem durkheimiana) de determinado grupo étnico.

À perspectiva de Leroi-Gourhan poderíamos aproximar a fenomenologia bachelardiana (Bachelard, 1990, 1991), que associa via os devaneios do repouso e da vontade a 'imaginação criadora' ao ato técnico configurador de objetos e espaços construídos - e prenhes de uma poética -, por intermédio de gestos instauradores de formas pelas quais os grupos sociais estetizam o mundo. Ora, se o corpo aparece como a dimensão carnal da existência da pessoa é porque, para além de sua materialidade, revela-se o receptáculo de significações que participam da atribuição de sentidos a si mesmo e ao mundo no qual interage como agente. Essa, a princípio, é a abordagem de Maurice Merleau-Ponty (1971) quando considera a relevância de uma fenomenologia da percepção, a qual jamais poderia ser entendida senão a partir da corporeidade daquele que percebe: há, assim, uma distinção - sem negar a comple-mentaridade - entre organismo-corpo e corporeidade, como indicaria Csordas (2008).

Tais autores inauguram reflexões inspiradoras que, associadas a abordagens mais contemporâneas, tanto na antropologia quanto na sociologia, produzidas no contexto brasileiro e internacional, nos auxiliam a compreender as formas como as sociedades "fazem uso de seus corpos", para evocarmos a perspectiva maussiana que encontra eco em Seeger, DaMatta e Viveiros de Castro (1987, p.11) quando os autores pensam acerca das sociedades indígenas amazônicas - mas que poderíamos estender às chamadas "sociedade caboclas" presentes nessa mesma "região etnográfica" - no que se refere à "originalidade" quanto à "elaboração particularmente rica da noção de pessoa, com referência à corporalidade enquanto idioma simbólico focal", considerando "ideologias nativas sobre a corporalidade". Por outro lado, Viveiros de Castro (1987, p.32), quando se refere à "fabricação do corpo" entre os Yawalapíti, indica que "a natureza humana é literalmente fabricada, modelada, pela cultura. O corpo é 'imaginado', em vários sentidos, pela sociedade"(grifo do original).

Nota-se que há significativa produção nacional acerca da temática do corpo, especialmente nos estudos compreendidos como antropologia do corpo e, por vezes, como 
antropologia da saúde1, cuja inspiração segue o pensamento de Luc Boltanski (1984), de Pierre Bourdieu (1977, 1994, 1998), entre outros autores, incluindo abordagens anglosaxãs, como as de Mary Douglas (1976), sobre pureza e impureza corporal, por exemplo.

As reflexões apresentadas neste artigo, no que tange ao corpo no contexto amazônico, vinculam-se à abordagem antropológica; no entanto, é preciso deixar claro que não serão discutidas necessariamente as relações entre corpo e saúde. Trata-se aqui de pensá-lo como meio e forma em devir no mundo, cuja simbólica instaura expressões culturais que identificam um ser para si, indissociável de suas paisagens de pertença. Um olhar sobre o corpo como dimensão existencial e sensível dos sujeitos no contexto amazônico pode auxiliar a compreensão das complexas interações bioculturais, como forma de nos aproximarmos da perspectiva do 'homem total' reivindicada por Mauss (1974).

Nesses termos, as cisões entre corpo e mente, sujeito e mundo, ser e paisagem, cultura e natureza perdem sentido (ver Ingold, 2000), uma vez que reivindicam um olhar integrador que rompe com os paradigmas da separatividade, a partir de hermenêuticas sensíveis à unicidade entre o anthropos e o oikos, em que "a corporeidade humana" faz sentido e produz sentidos nas interações com o mundo, pois "o corpo é o vetor semântico" (Le Breton, 2006, p.7) que evidencia tais relações.

O artigo é fruto de uma pesquisa etnográfica de maior âmbito junto aos moradores da ilha do Maracujá, situada no estado do Pará, e busca apontar alguns caminhos, bem como possíveis interpretações sobre as maneiras como as pessoas lidam com o equilíbrio corporal, a partir de suas experiências cotidianas com os terrenos insulares e o tráfego pessoal diário nas embarcações que cruzam constantemente os cursos hídricos da região.

"O Maracujá" - como é chamada a ilha por seus moradores - compõe a área metropolitana de Belém, a partir da determinação legal de distritalização de seu espaço geopolítico, uma vez que se tornou parte do distrito administrativo do Outeiro, juntamente com mais 26 ilhas, formadoras do complexo insular que pertence à capital paraense. A ilha ocupa área de $6.465 .916,11 \mathrm{~m}^{2} \mathrm{e}$ está situada à margem esquerda do rio Guamá, tendo à sua frente a ilha do Combu; ao leste, o município do Acará; ao sul, a ilha da Juçara; mais abaixo, a ilha de Itacoãzinho; a oeste, a ilha dos Papagaios; e, por trás, a ilha das Onças, a mais extensa de todas as ilhas do sul.

Os ecossistemas que constituem a ilha sofrem a influência direta das marés dos rios que a circundam. Os mais caudalosos são os rios Guamá e Pará, ou Guajará, suscetíveis a variações sazonais, principalmente no período de dezembro a abril, quando ocorrem constantes inundações, daí a caracterização do solo como sendo de várzea, seguindo uma rítmica que para Leroi-Gourhan é criadora do espaço e do tempo (que aqui poderíamos chamar de espaço e tempo ribeirinhos) - relacionada ao fluxo das águas, que configura as formas de sociabilidades, as práticas e as vivências dos sujeitos (Harris, 1998b).

Sabe-se, a partir de trabalho de campo, que moram na ilha do Maracujá aproximadamente 150 famílias, distribuídas esparsamente ao longo de toda a sua extensão. A população é etnicamente heterogênea, porém, nota-se presença negra significativa. Este artigo não adentra a discussão acerca das chamadas comunidades quilombolas, porque se trata de um tema complexo que nos conduziria por outros caminhos de reflexão. 
O projeto Nova Cartografia Social da Amazônia (s.d.), fascículo 8, "Ribeirinhos das ilhas de Belém", emprega, como visto, a categoria 'ribeirinho'. Essa categoria, para o caso que interessa aqui, ressalta os modos de vida relacionados às práticas técnico-culturais de manejo das terras de várzea ou, mesmo, do curso fluvial por meio das práticas de pesca, por exemplo. Delma Pessanha Neves (2009), por sua vez, faz uso da expressão 'ribeirinhosagricultores de várzea' em suas pesquisas no médio rio Solimões (AM). Outra categoria comumente utilizada para denominar tais populações é 'caboclo'², termo aqui utilizado, ainda que com certa parcimônia, uma vez que os moradores da ilha do Maracujá não se autoidentificam como tais, utilizando, com alguma frequência, as expressões 'ribeirinho' - ou ainda 'nós, do sítio', 'nós que somos do interior' ou 'nós, da mata'. Por outro lado, no complexo jogo político-identitário amazônico, é bem possível que façam uso do termo caboclo quando necessário.

\section{A outra margem do rio}

O olhar que alcança a outra margem do rio Guamá e vislumbra uma paisagem verdejante e densa, cuja exuberância revela certa homogeneidade à perspectiva distanciada, certamente se surpreenderá ao aproximar-se e descobrir que o panorama avistado é, na realidade, o de uma trama complexa de labirintos nos quais os furos ${ }^{3}$ e os igarapés indicam a existência de um intrincado universo de ilhas. Trata-se de uma paisagem que se interioriza e adensa, sendo o cotidiano e as experiências simbólico-práticas de seus moradores, apesar da proximidade com a metrópole ${ }^{4}$, ainda pouco conhecidos pela antropologia.

$\mathrm{O}$ artigo em questão busca adentrar tais meandros a partir de um olhar etnográfico que contempla o cotidiano dos seus habitantes, mais especificamente via as formas sensíveis (Sansot, 1986) presentes na vida social ribeirinha, a fim de perceber as suas sutilezas quanto ao uso dos corpos - as formas perceptíveis - para nos aproximar de Bourdieu (1977). Inspiramo-nos, ainda, em Certeau (1994) para pensar as 'táticas' corporais elaboradas por seus moradores ao praticar as suas paisagens de pertença.

Táticas dessa ordem implicam o exercício postural que traduz um conjunto de gestos e técnicas corporais construídos por pessoas que passam boa parte de seu cotidiano sobre os barcos, realizando travessias e percursos diversos pelo rio Guamá, a fim de efetuar suas atividades, laborais ou não. Para tanto, foi considerado o formato de acomodação e de equilíbrio às embarcações que percorrem os cursos d'água que banham as ilhas, pois são capazes de revelar expressões corporais pelas quais as pessoas vivenciam e manifestam sua corporeidade em relação aos barcos no seu constante trafegar pela região fluvioinsular.

É por isso que se procurou trazer à tona o tema relativo à mobilidade dos sujeitos para além de seus territórios, envolvendo um fluxo constante entre as margens opostas do rio a continental e o seu 'vitalismo' (Maffesoli, 1987), não menos exuberante na proliferação de agenciamentos coletivos e de arranjos socioeconômicos e políticos, através de um lugar emblemático para as formas de viver locais - incluindo-se a sociabilidade (Simmel, 1983) e para o comércio ribeirinho, como é o porto do Açaís; e à mobilidade que chamaremos aqui de ilhoa, na sua riqueza bioetnodiversa, pautada em complexas interações ecoantropológicas configuradoras de paisagens e de vínculos simbólico-afetivos com os lugares de perten- 
cimento por parte dos grupos familiares que lá vivem, mas profundamente ligados ao mundo urbano belenense.

Cenários culturais cuja sutileza dos jogos socioespaciais é dinamizada pela presença do rio no cotidiano das pessoas que praticam os lugares (Certeau, 1994): o seu curso é o fluxo intenso por onde singram barcos que, de ribeira em ribeira, integram o homem e o meio, de forma indissociável. Esse fenômeno não ocorre apenas porque manejam os ecossistemas que compõem o vasto arquipélago, mas também devido ao fato de valorizarem uma pertença à ilha em que nasceram ou moram, diferenciando-se dos moradores das demais ínsulas. É importante ressaltar que os rios do entorno dão nome às ilhas, esses rios diferenciam os moradores de cada uma das ínsulas, como também, os moradores de uma mesma ilha.

Para exemplificar tal questão, nos apoiamos na fala de uma das informantes, dona Jesus, ao explicar, durante uma conversa, que os moradores situados à margem do furo do Benedito - que banha as ilhas do Combu e do Maracujá - se denominam moradores do Benedito e não do Combu ou do Maracujá. Parece que tais moradores, por vezes, acabam por ignorar a pertença à ilha, restringindo-se ao furo.

Por isso, a potência das imagens da água e da ilha se entrelaça à dinâmica daquilo que aqui se poderia chamar de um imaginário caboclo-ribeirinho, pois, como as águas, os caboclos/ribeirinhos revelam fluxos, ou ainda, devires identitários transfronteiriços com implicações socioestéticas e éticas complexas, ao mesmo tempo em que podem indicar uma ideia de 'ilheidade' (Diegues, 1997), de pertença a um contexto que os identifica no campo das relações sociais como oriundos de um lugar que os singulariza em relação aos não moradores das ilhas. Há, assim, uma unidade na diferença que, seguindo uma inspiração simmeliana, faz pensar na presença de algo como um ideal insular (Simmel, 1996a).

No entanto, no entendimento dos moradores, o local onde moram, antes de ser uma ilha é, na realidade, 'um sítio'. No caso de pensarmos um ideal insular como um elemento que os agrupa e identifica em torno de certos interesses comuns, podemos fazer referência aos momentos de conflito (Simmel, 1983) com as políticas públicas ligadas à saúde oriundas da metrópole - como o problema relativo ao uso das rasas ${ }^{6}$ (ou paneiros) e a contaminação do açaí pelo Trypanossoma cruzi -, em 2007, quando os moradores de várias ilhas se uniram em defesa da utilização dos recipientes artesanais no comércio do açaí, fruto mais importante do extrativismo ilhéu.

\section{Formas e sentidos: a corporeidade como expressão do estar no mundo}

Em 1934, depois de observar nos corpos humanos uma diversidade de formas de ação, Marcel Mauss (1974, p.211) buscou compreender tal fenômeno chamando-o de técnicas corporais, como bem definiu, "as maneiras como os homens, sociedade por sociedade e de maneira tradicional, sabem servir-se de seus corpos". Segundo o autor, toda técnica tem sua forma, e é assim com toda atitude corporal.

O corpo humano seria a primeira ferramenta do homem e seu primeiro objeto técnico, sendo ao mesmo tempo um meio - um processo - pelo qual os movimentos que dão forma e concretizam as suas ações se efetivam como um conjunto de técnicas e de gestualidades relativas a um grupo étnico. Estamos, dessa maneira, na esfera do corpo enquanto um 
construto social relativo à experiência cultural dos sujeitos, indo além da perspectiva fisiológica do organismo, sem dela prescindir. Portanto, "o homem não é o produto do corpo, [pois] produz ele mesmo as qualidades do corpo na interação com outros e na imersão no campo simbólico. A corporeidade é socialmente construída" (Le Breton, 2006, p.18-19).

Mauss (1974) reforça que as técnicas corporais, mesmo sendo atos mecânicos, são construídas e dispostas na pessoa pela sociedade em que está inserida. Chama atenção para o fato de que essas técnicas encaixam-se num sistema de montagens simbólicas valorativas que enfatizam alguns atos em detrimento de outros. Tais técnicas apresentam variações por idade, por sexo, por rendimento e por transmissão do ensino das mesmas. Nota-se, ainda, que a técnica para Mauss seria "um ato tradicional eficaz" sendo, por isso, necessariamente transmitida. Por outro lado, a sua transmissão é possível devido às formas tradicionais e eficazes de repassá-las (uma tecnologia nos termos de um saber sobre a técnica passível de ser apre[e]ndido). $\mathrm{O}$ autor ainda aponta o fato de que anterior às "técnicas com instrumentos, há o conjunto de técnicas corporais" (p.218).

Nesse sentido, interessa-nos a perspectiva de Mauss (1974, p.213-215) que alia seus estudos ao conceito de hábito, uma vez que "[c]ada sociedade tem hábitos que lhe são próprios". Conforme o autor os “'hábitos' variam não simplesmente com os indivíduos e suas imitações, mas, sobretudo, com as sociedades, as educações, as conveniências e as modas, com os prestígios". Daí indicar que os movimentos corporais são imitações de ações bemsucedidas, quando a "criança, como o adulto, imita atos que obtiveram êxito e que ela viu serem bem-sucedidos em pessoas em quem confia e que têm autoridade sobre ela".

Haveria, ainda, nos parece, um formismo no sentido simmeliano, pelo qual as técnicas corporais - correlacionando expressão corporal, gesto e ferramenta - estariam intimamente relacionadas às formas sociais, ambas cooperando no devir humano nos lugares praticados quanto à sua existência e produção de significados no tempo, compartilhados pelos grupos sociais no âmbito das relações sensíveis com o mundo, uma vez que, "além de ser uma entidade técnica, o corpo e seus modos de uso marcam uma identidade" (Arreguí, 2008, p.34) que, para o caso caboclo-ribeirinho no contexto amazônico, é algo extremamente complexo.

A perspectiva de Georg Simmel $(1983,1996 b)$ considera as interações humanas por meio dos sentidos, apontando para a relevância do sensível na experiência cotidiana dos sujeitos. Dessa maneira, quando se trata de pensar o formismo enquanto processo que se dá na ação, é preciso ter claro que a cultura, via incorporação dos gestos e do habitus (Mauss, 1974; Elias, 1994; Bourdieu, 1994; Wacquant, 2003; Csordas, 2008), engendra formas expressivas que estetizam a vida social à medida que as pessoas interpretam e atribuem significados ao mundo que constroem e com o qual interagem. Nesses termos, a "corporeidade humana como fenômeno social e cultural, motivo simbólico, objeto de representações e imaginários" (Le Breton, 2006, p.7) participa intensamente desse processo de significação.

A noção de habitus como aparece em Elias (1994, p.9), relativa "à autoimagem e à composição social dos indivíduos", coloca as tensões e as recursividades entre indivíduo e 
sociedade, implicando dialeticamente seu mútuo engendramento. Tal processo envolve necessariamente constrangimentos e negociações colocados ao indivíduo diante do social. Ora, Bourdieu (1994) mostrou muito bem como o habitus é estruturante na experiência dos agentes, enquanto disposições duráveis, mas também como é possível não apenas reproduzir tais conformações e valores interiorizados e vividos de forma prática - uma economia simbólica das práticas - no corpo, uma inscrição na carne. Ser durável, como mostrou Wacquant (2003, p.14) em suas reflexões sobre o habitus, não significa dizer eternamente estático. O agente social atua de maneira a transformá-lo, o que nos aproximaria de Certeau (1994), pois seriam elaboradas táticas para burlar determinadas situações colocadas aos sujeitos. ${ }^{7}$

O corpo, portanto, é uma paisagem em que se dão os jogos entre autoimagem e alteridade; entre mudança e perdurância; entre constrangimentos e buscas de liberdade, pois nele confluiriam as formas sociais conflitantes que se coadunariam aos ou desafiariam os poderes instituídos em relação aos agentes, que em verdade são sujeitos desejantes e sensíveis ao contexto no qual interagem, uma vez que o "corpo é similar a um campo de força em ressonância com os processos de vida que o cercam" (Le Breton, 2006, p.26).

Merleau-Ponty (1971, p.155), por sua vez, referindo-se a Grunbaum, faz alusão à questão do hábito, que, segundo o autor, "exprime o poder que temos de dilatar nosso ser no mundo, ou de mudar de existência anexando em nós novos instrumentos". Tal afirmação torna-se mais interessante à nossa discussão, por exemplo, quando consideramos que nem todos os moradores da ilha do Maracujá nasceram naquele lugar.

Um número significativo de pessoas com as quais conversamos é originário da porção continental de Belém. Elas foram residir na ilha ainda crianças, enquanto outras passaram a morar no local já adultas, como é o caso dos membros de algumas famílias que colaboram com a pesquisa. Seguindo as indicações de Merleau-Ponty, podemos afirmar que tais pessoas experimentaram essa 'dilatação do ser', ou ainda, essa mudança de existência (corporal, inclusive) que menciona o autor.

Merleau-Ponty (1971, p.83), por sua vez, ao considerar o corpo - que, segundo ele "é meu ponto de vista sobre o mundo" - um dos objetos presentes nele, indica que "[u]m movimento é apreendido quando o corpo o compreendeu, isto é, quando ele o incorporou a seu 'mundo', e mover o corpo é visar através dele as coisas, é deixá-lo responder à sua solicitação, que se exerce sobre ele sem nenhuma representação" (p.150). Ou ainda, "[h]abituar-se com um chapéu, com um carro, ou um bastão, é instalar-se neles, ou inversamente, fazer com que eles participem da voluminosidade do corpo próprio" (p.155).

Para o autor a "experiência do corpo próprio nos ensina a enraizar o espaço na existência" (Merleau-Ponty, 1971, p.159), e insiste que não devemos comparar o corpo a um objeto físico, "mas antes à obra de arte" (p.161). Thomas Csordas (2008, p.370) realiza uma reflexão interessante sobre as relações entre o pensamento de Merleau-Ponty e Bourdieu, pois, segundo esse autor, reconsiderar os seus estudos "sugere pôr em relevo as noções de percepção e prática" no que tange ao corpo. 


\section{Entre o continente e as ilhas, ou a mirada de horizontes e de margens}

Nas constantes idas e vindas à ilha do Maracujá ${ }^{8}$ é possível observar a dinâmica relacionada ao deslocamento de moradores que realizam frequentemente a travessia em direção à margem de Belém, sendo que, para algumas pessoas, ela pode ocorrer várias vezes ao longo do dia, conforme a necessidade, como informou dona Fátima - moradora da ilha e uma das lideranças locais.

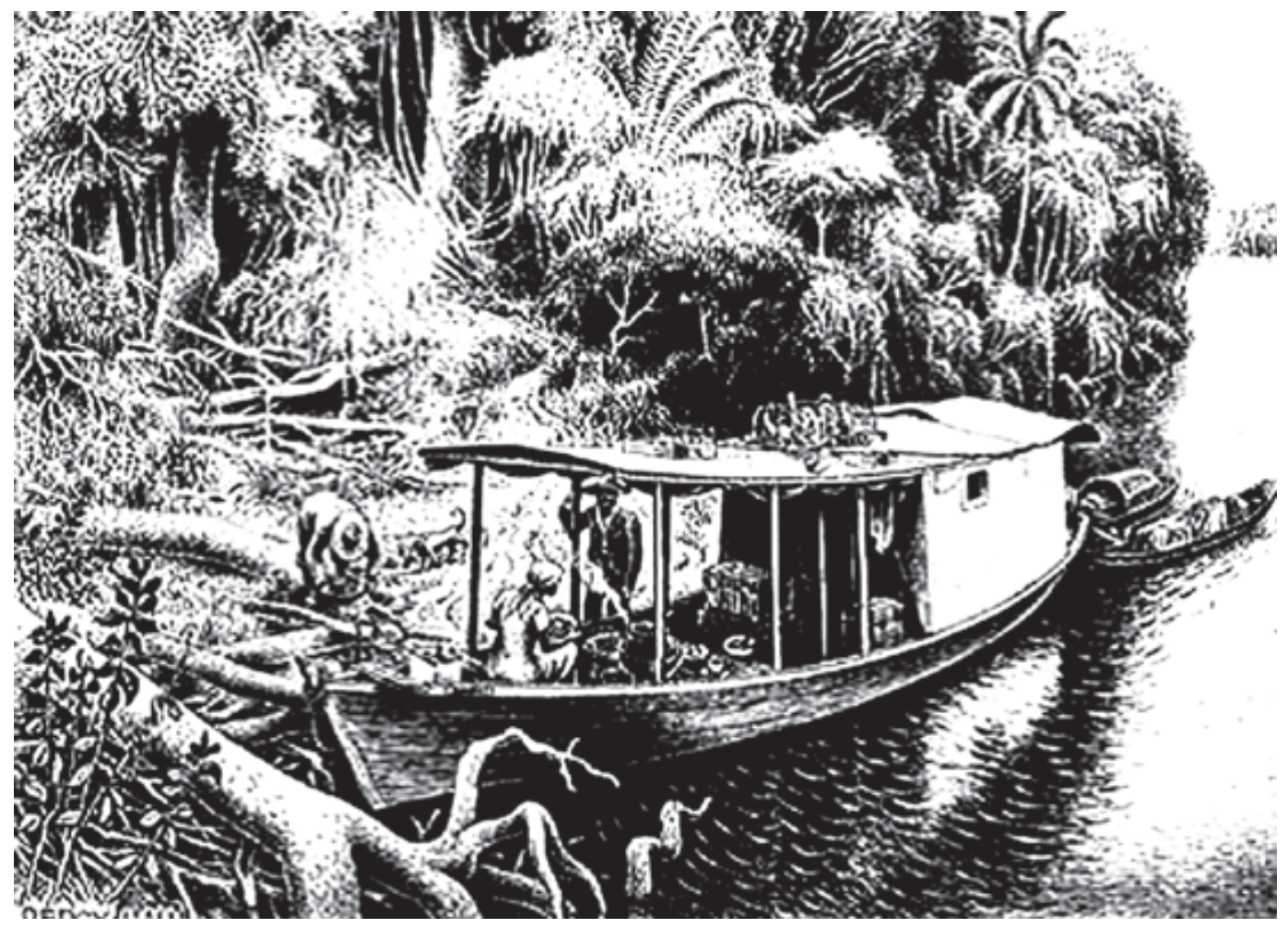

Fonte: gravura de Percy Lau (Angotti-Salgueiro, 2005)

Nota-se que o intenso comércio de açaí, bem como de cacau (durante a entressafra do fruto da palmeira), associado à ausência de recursos materiais nas ilhas, liga-os à outra margem diariamente, seja na busca de alimentos, água, serviços relativos à energia elétrica (carregamento de baterias de celulares, aquisição de gelo, levar o açaí para ser batido na máquina, entre outros), medicamentos, vestuário, seja para vender o açaí ou o caroço do cacau nos portos da cidade de Belém.

Durante os deslocamentos de uma margem à outra, os navegantes, não raro, enfrentam a força da 'maresia' e as inúmeras vagas do rio. Quando revolto, o Guamá lança as embarcações a uma instabilidade em seus rumos que pode desorientar a travessia, 'jogando' o barco constantemente. É nesse contexto de conturbada interação com o curso d'água, quando todos estão no mesmo barco, que se torna possível vislumbra além das práticas de solidariedade e de apoio mútuos, os usos dos corpos pelas pessoas e as suas técnicas 


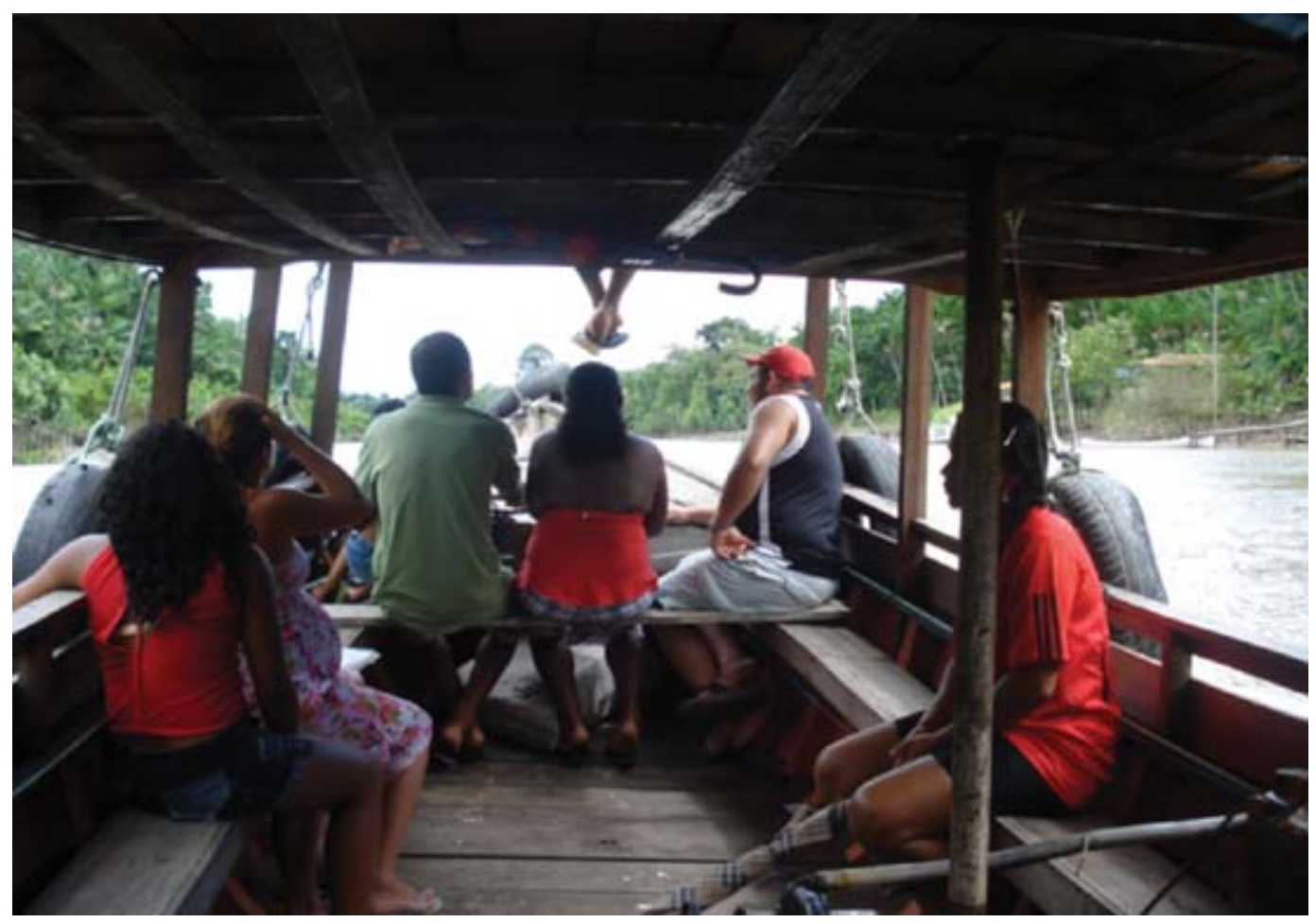

Fonte: acervo pessoal dos autores

de praticar o espaço da embarcação ao longo do deslocamento fluvial, envolvendo formas de tensão e de relaxamento corporais (Mauss, 1974; Bastide, 1983; Barba, Savarese, 1995).

Nessas situações, percebem-se a agilidade e o equilíbrio dos corpos nas estratégias engendradas pelos sujeitos-viajantes, de maneira a se manter numa posição/postura que lhes forneça segurança e conforto durante a travessia do rio em direção às suas moradias, ou à casa de um parente, situada na outra margem. Entre as formas posturais e de busca de segurança poderíamos mencionar, por exemplo:

(1) apoiar-se nas bordas do barco;

(2) manter-se de pé em equilíbrio diferenciado - mantendo firmeza no apoio dos pés sobre o assoalho do barco -, podendo executar uma tarefa (jogar a rede, remar, caminhar, trocar de roupa, entre outras atividades possíveis);

(3) permanecer deitado;

(4) segurar-se com firmeza nos apoios;

(5) manter-se sentado (segurando o banco ou não), podendo, ainda, estar comendo, se maquiando ou lendo, por exemplo;

(6) apoiar-se/segurar-se em alguém mais bem posicionado e mais seguro, especialmente quando não se tem o habitus de deslocar-se na água.

Portanto, trata-se do equilíbrio necessário para o translado nos barcos, que se podem constituir em canoas de pequeno porte, motorizadas ou não, bem como embarcações 
maiores. O balanço das águas do rio Guamá, dependendo do tipo de condução utilizada, tende a exigir das pessoas que o transpõem muita flexibilidade e equilíbrio, a fim de lidar com a rítmica do rio, que nem sempre se revela um 'tapete' - no sentido da calmaria, como afirmam alguns moradores das suas beiradas.

É comum aos residentes da ilha a prática de diversas formas de equilíbrio corporal aprendidas desde a infância, as quais se relacionam ao acúmulo de experiências - entendidas aqui a partir da perspectiva de Csordas (2008, p.368), como expressão da "significância do significado" - no decorrer de suas trajetórias pessoais, resultando em "experiências corporificadas". Sendo assim, o equilíbrio ${ }^{9}$, habilidade humana capaz de manter o corpo ereto, de maneira a mover-se no espaço nessa posição (Barba, Savarese, 1995, p.34-35), é experimentado no cotidiano ilhéu sobre uma superfície constantemente vacilante, não firme.

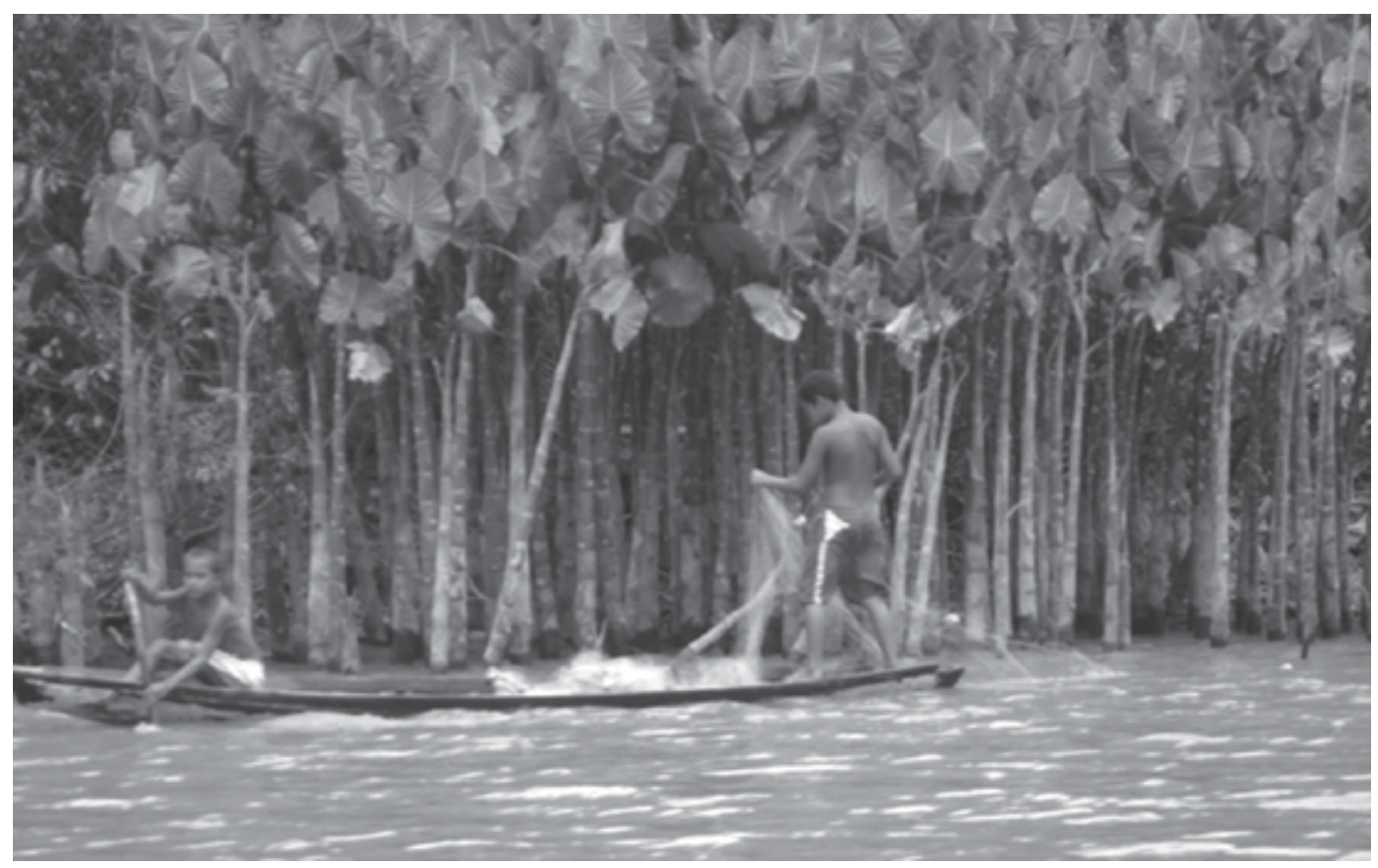

Fonte: acervo pessoal dos autores

Os homens, as mulheres e as crianças executam performances corporais ligadas a atividades diversas, em que o gesto técnico associa-se à plasticidade corporal na execução das diversas tarefas, como manter-se em cima dos barcos, pescando ou deslocando-se de um lugar a outro; subindo nos açaizeiros para apanhar os frutos, utilizando-se da peconha ${ }^{10}$; carregando os pesados paneiros de açaí sobre os ombros de uma localidade à outra, tendo que se deslocar por estreitas pontes de madeira que separam as casas, pois o terreno da ilha, sendo um chão de várzea, constitui-se em um substrato lodoso ou inundado. Não raro, os homens trabalham embarcando/desembarcando as rasas nas pontes do porto, que muitas vezes balançam ou possuem tábuas soltas, além do fato de que homens, mulheres e crianças 


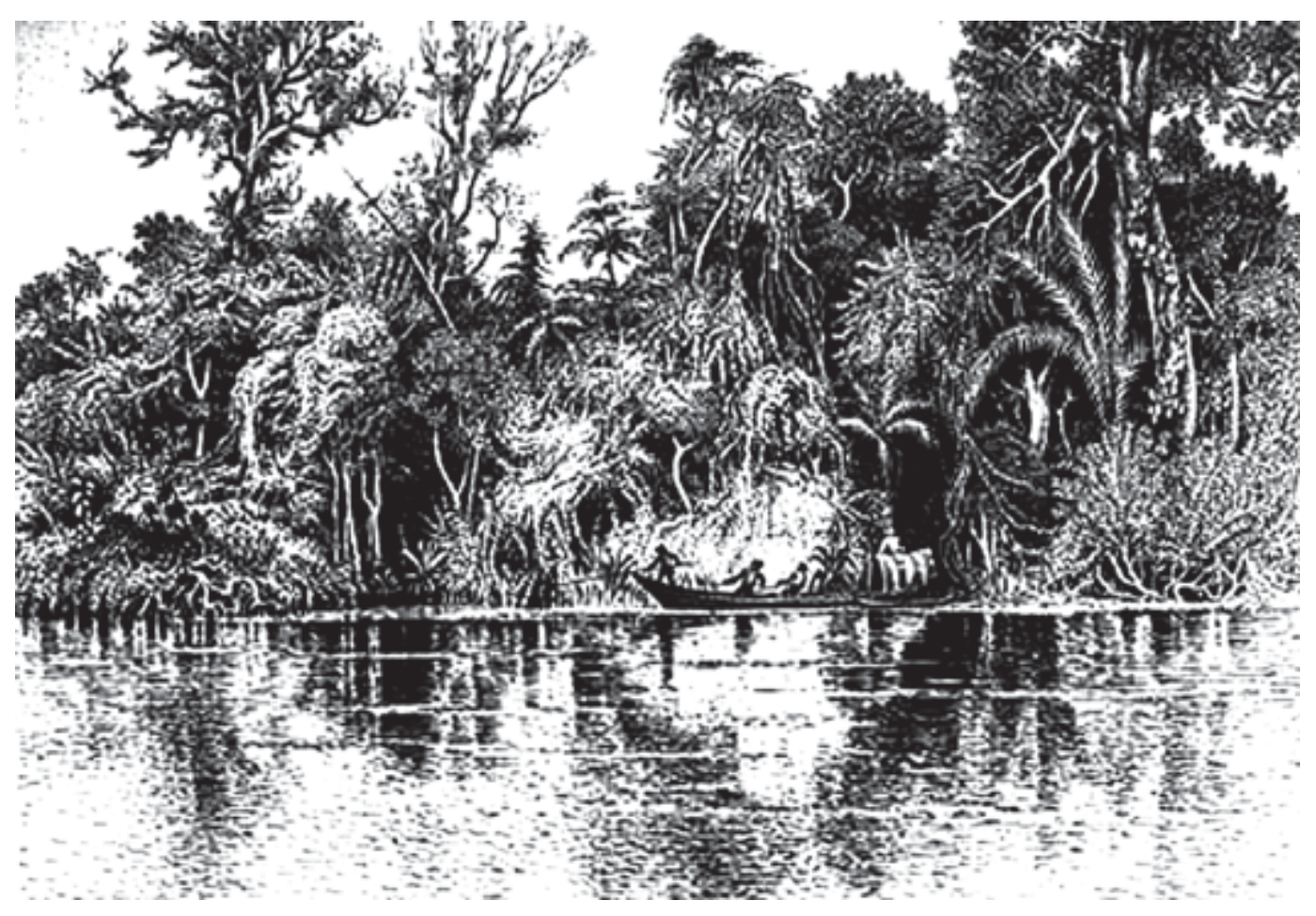

Fonte: gravura de Percy Lau (Angotti-Salgueiro, 2005)

carregam os mantimentos necessários à sobrevivência na ilha em fardos de tamanhos variados. Destarte, os ribeirinhos exercitam o equilíbrio tanto durante o tráfego nos barcos quanto em espaços da margem insular, onde construíram as suas residências.

Tanto nas margens insulares quanto nas continentais, as pessoas circulam sobre as pontes, as passarelas e os portos. Trata-se, dessa maneira, de espaços de trânsito diário dos moradores nos quais é necessário cotidianamente colocar em prática o jogo complexo entre tensão e equilíbrio, de forma a manter-se sobre as superfícies nem sempre estáveis. Isso também é verdadeiro para as situações em que precisam movimentar-se sobre os finos troncos nos alagados, onde se localiza o açaizal em que exercem a coleta do fruto da palmeira.

Na outra margem do rio Guamá (a porção continental da metrópole), percebe-se que a necessidade de equilíbrio não é menor, pois a armação de madeira do porto, já um tanto gasta devido ao intenso uso, possui um número significativo de tábuas soltas e apodrecidas, cuja instabilidade a faz balançar com o peso dos corpos e das rasas de açaí, de cacau, de farinha, dos garrafões de água, entre outros materiais que são ali depositados à espera do embarque ou desembarque. Os trapiches recebem relevante fluxo de pessoas no ir e vir pelo Guamá.

Sabe-se que o porto não oferece condições de uso, uma vez que atualmente se encontra interditado devido ao fato de a armação de madeira não suportar o peso do material transportado no local, mas funciona assim mesmo, exigindo dos moradores o mesmo equilíbrio e agilidade para frequentá-lo. 
Flávio Leonel Abreu da Silveira, Terezinha de Fátima Ribeiro Bassalo
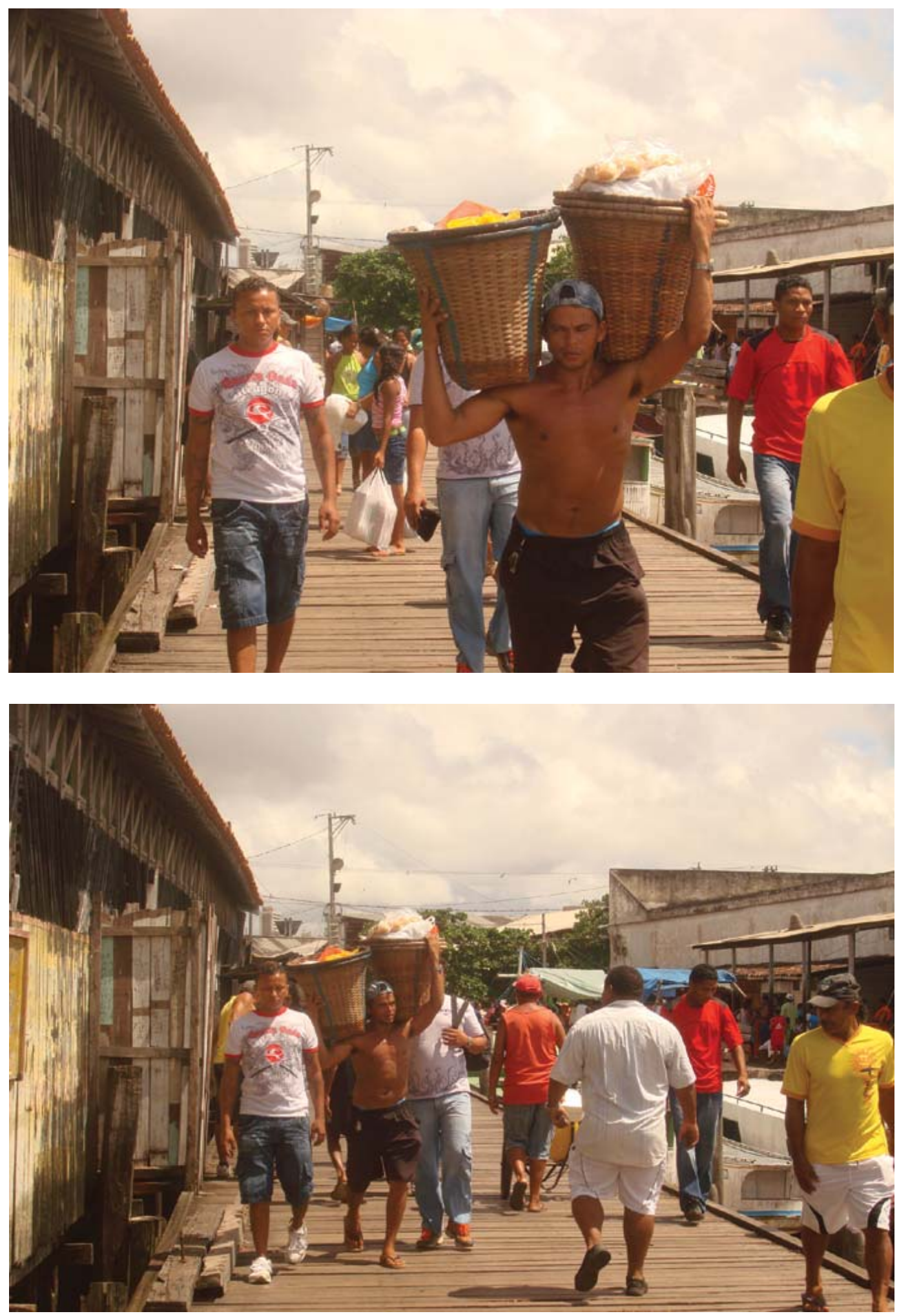

Fonte: acervo pessoal dos autores 
A experiência cotidiana das pessoas não é aquela de pisar chão firme, representada por certa estabilidade do terreno, mas a de contato com uma superfície vacilante, alagadiça e, na sua maior parte, pendente - pontes e trapiches, por exemplo - que as leva a exercitarem outro tipo de contato com o solo, muito diverso daquele experimentado pelos que habitam a terra firme. Nesse contexto inseguro, o ponto de equilíbrio varia, e as formas de relação com o espaço também, exigindo um saber corporal próprio para o deslocamento, incorporado nas suas ações, decorrente de uma 'experiência corporificada', identificada com práticas culturais vividas na intensa relação com o espaço e o tempo amazônicos.

A figura humana no contexto ilhas-continente se projeta nos barcos e demais embarcações ou perambula em suas atividades nas beiras das ilhas, onde as moradias se situam às margens; sendo assim, as pessoas que permanecem nas ínsulas estão sempre nas beiradas, que é justamente o espaço habitável, indo esporadicamente ao interior das mesmas. Todavia, são recorrentes as imagens de pessoas deslocando-se no porto - a outra margem do rio e borda do continente urbano.

Nota-se que, pelo fato de as casas estarem todas situadas nas margens do rio, as suas portas de entrada estão posicionadas em direção ao curso d'água, uma vez que as vias "aqui as nossas ruas são o rio", disse certa vez a moradora Dienne - são os pequenos braços, igarapés e furos dos rios Guamá e Pará. Portanto, as pessoas que estão na ilha do Maracujá permanecem a maior parte do tempo à beira, que é justo onde se vive. Desse modo, o sair de casa pela porta da frente significa seguir em direção às águas, enquanto a porta dos fundos está direcionada à mata.

É no interior da ilha que estão distribuídos os açaizeiros, pois no seu cerne se concentram as palmeiras que fornecem a principal fonte alimentar (a ingestão do seu fruto está, geralmente, associada ao peixe e à farinha de mandioca) e de renda dos moradores 'do Maracujá', o açaí. Para coletar esse fruto, os moradores percorrem terrenos alagadiços, certas vezes com água até o pescoço, conforme descrito por alguns deles, pois, segundo seu Abaeté, quanto mais alagado o terreno e mais 'dentro da mata', melhor é o fruto.

Superadas as distâncias, os coletores de açaí sobem nas árvores, a fim de colher os

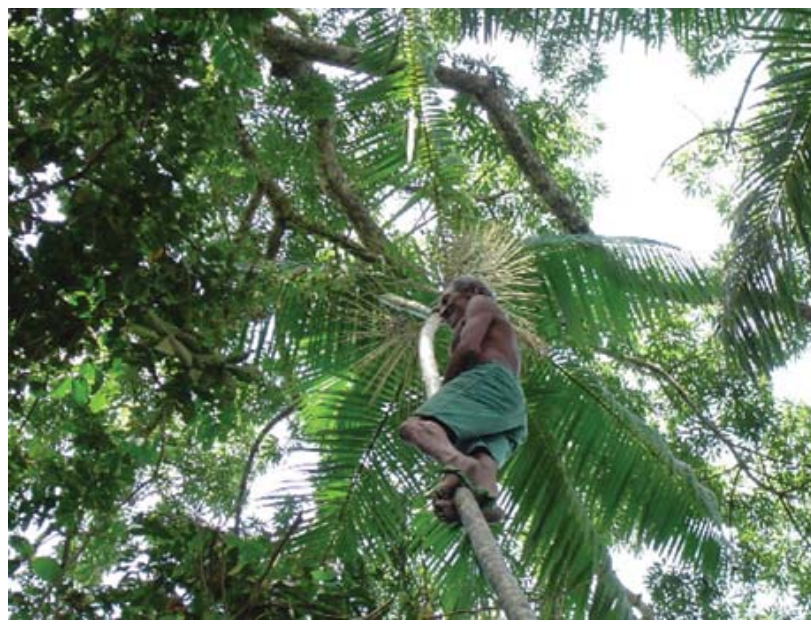

Fonte: Subindo no açaizeiro, 2011. cachos localizados em sua porção superior; debulham os frutos nos paneiros, transportando-os ao porto do Açaí, situado à beira do rio Guamá junto ao bairro do Jurunas, em Belém, onde são comercializados.

De acordo com as reflexões de Barba e Savarese (1995, p.34-35), um corpo em equilíbrio apresenta-se ereto e móvel no espaço. A partir daí, para mantê-lo nessa situação é necessária uma série de relações musculares e tensões no interior do organismo. Os autores consideram em seus estudos a existência de corpos em superfícies sem alterações, uma vez que são os corpos que se apresentam alterados. Porém, para o caso deste estudo, é a superfície que se mostra 


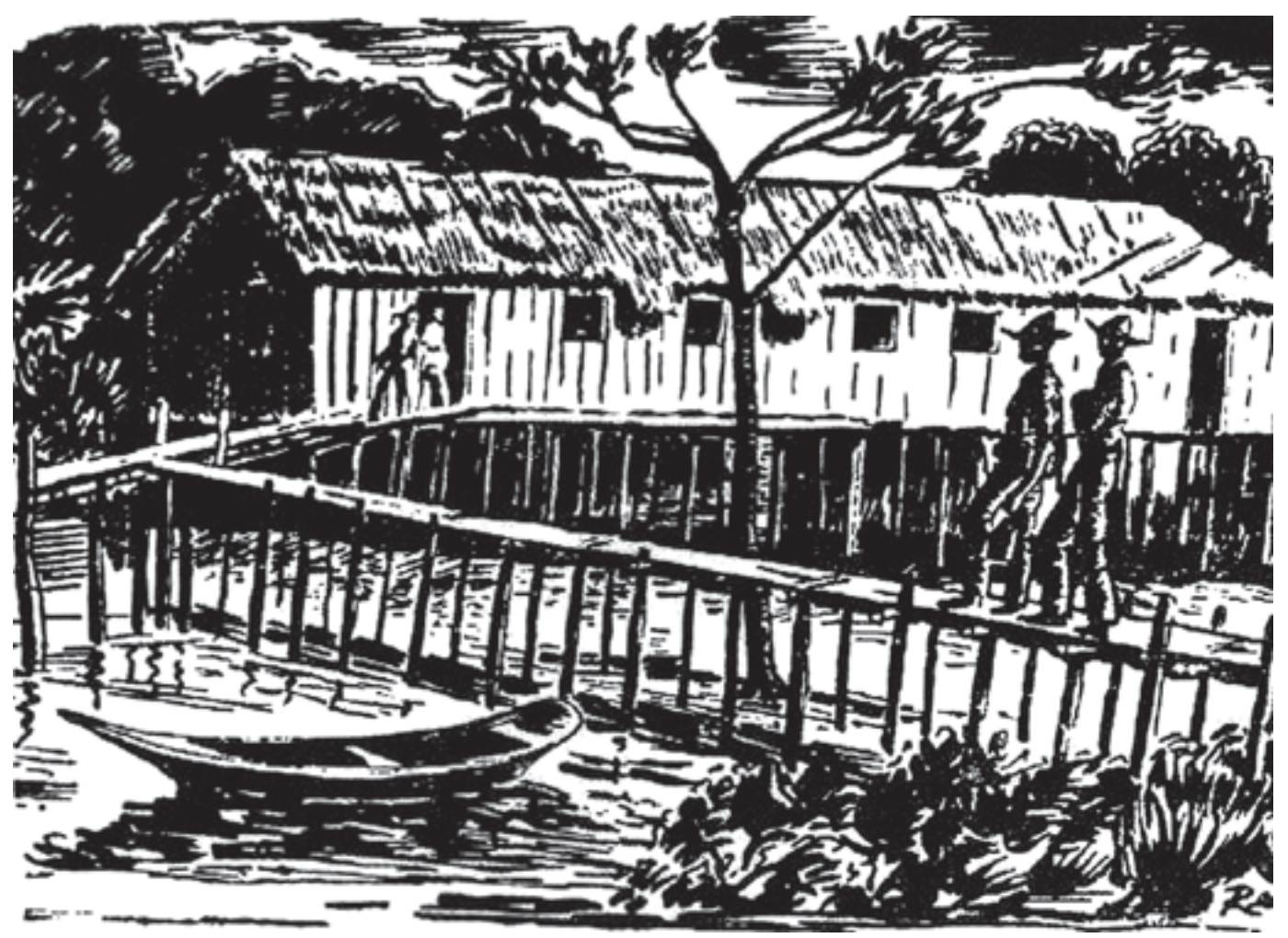

Fonte: gravura de João José Rescala (Wagley, 1988, p.118)

modificada, vacilante, não firme. É possível afirmar que tal condição corporal exige tensão redobrada por parte das pessoas, resultando, por isso, em corpos mais tensionados e tonificados.

Na ilha do Maracujá, caminha-se sobre armações de madeira para entrar e sair de casa, a fim de se deslocar nos terrenos alagadiços à beira do rio Guamá, pois, como já mencionado, as moradias localizam-se às margens do rio. É preciso deixar claro que não há ocupação humana no coração da ilha. A beira é o lugar de viver, em oposição ao interior, cujo núcleo se alcança por intermédio de trilhas constantemente praticadas - um lugar antropológico (Augé, 1994) por excelência no contexto florestal amazônico - que conduzem ao local da labuta por entre as matas e os igarapés da região.

As moradias possuem pontes de madeira (ver imagem acima) que funcionam também como atracadouros para os barcos, incluindo passarelas que dirigem as pessoas da casa ao rio e vice-versa. Muito úteis durante os períodos de cheia, possibilitam o acesso fácil ao transporte fluvial tão necessário ao deslocamento de todos.

Por isso mesmo, na maioria das casas aparecem estendendo-se ao longo da beira da ilha, onde estão ancorados os barcos que variam em tamanho e modelo, podendo apresentar teto ou não; com ou sem motor, de acordo com as posses do morador. É bastante comum encontrarem-se moradores que, pelo fato de não possuir barco, dependem exclusivamente do transporte de outros moradores, como vizinhos, por exemplo. A carona é uma prática que indica formas de negociação e de solidariedade entre ilhéus. 


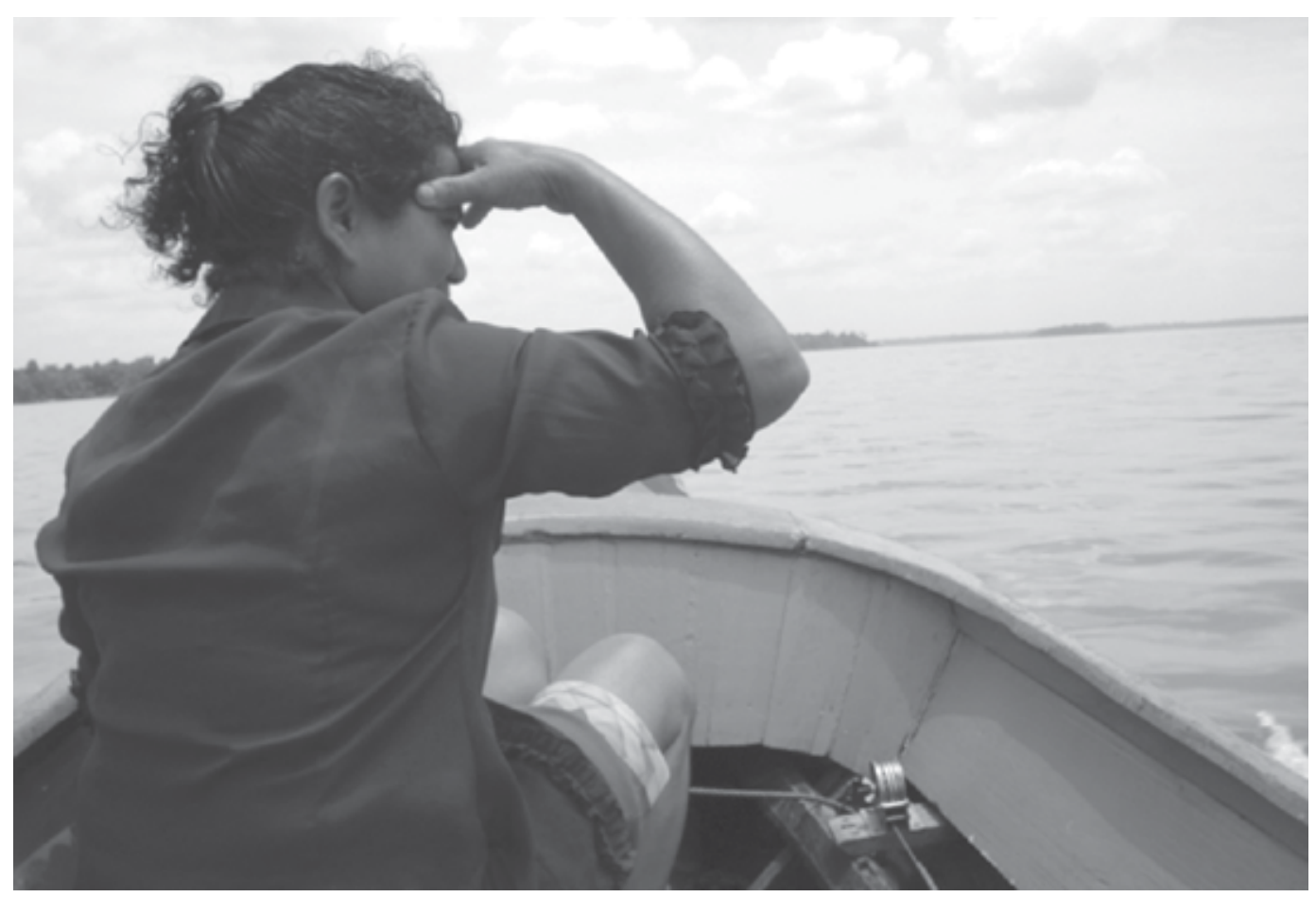

Fonte: acervo pessoal dos autores

O cotidiano dos moradores da ilha do Maracujá, seja no contexto insular ou metropolitano, exige balanço e equilíbrio de corpos não muito leves, pois, em uma rápida observação, pode-se perceber que os moradores da ilha, bebedores de açaí e consumidores de farinha, tanto os homens quanto as mulheres, possuem corpos fortes e musculosos, quando não obesos. Usualmente, vestem bermudas, sendo comum as mulheres usarem bermudas de lycra embora seja possível também vê-las, geralmente no caso de membros de Igrejas evangélicas, com vestidos e saias colocados por cima das bermudas, como aparece na foto.

A constância na busca de equilíbrio exige interações com os ambientes que, por certo, se diferenciam das que praticam aquelas pessoas que não a vivenciam cotidianamente, exigindo táticas e formas sociais para lidar com os corpos que seriam distintas porque apreendidas ao longo da experiência cultural, revelando uma adaptação biopsicossocial ao contexto vivido. Nesse sentido, parafraseando Mauss (1974), pode-se dizer que estamos diante de técnicas corporais de margens insulares-continentais, haja vista as peculiaridades das populações das ilhas em manter-se numa situação de estabilidade corpóreo-motora sobre superfícies nem sempre firmes, ora na margem insular, ora na margem continental.

A procura de estabilidade exige das pessoas agenciamentos subjetivos e cognitivos uma dimensão assimiladora e acomodadora em relação às pulsões e vicissitudes do meio, vividas cotidianamente como acúmulo de experiências e elaboração de respostas -, indicando um 'trajeto antropológico", como aponta Gilbert Durand (1989), dinamizando, assim, um conjunto de representações e símbolos consubstanciados nas imagens que habitam 
o universo ilhéu (imaginário). Tais imagens se ligam às formas inteligentes e criativas de operar com o meio (social e ambiental), assim como a uma vivência emocional que as predispõem a lidar com as tensões colocadas no jogo equilíbrio/desequilíbrio que se apresenta em seus cotidianos, engendrando um 'gênio'/um arcabouço de saberes e fazeres relacionados com as vivências ribeirinhas.

Se as margens constituem fronteiras capazes de ser atravessadas, revelando possíveis devires para além dos territórios - desterritorializações/reterritorializações que indicam trânsitos envolvendo o fluxo ilhas/continente-metrópole/ilhas - é porque a simbólica relativa a certo nomadismo é uma realidade cotidiana para uma parcela significativa dos coletivos humanos que fazem das ilhas seus territórios-paisagens de pertencimento. A dimensão insular, dessa forma, implica um 'território-mito' (Maffesoli, 1994), uma quimera - 'um lugar calmo', como diria dona Edna, uma das entrevistadas -, assim como o continente é o destino em que a potência do viver urbano presentifica a heterogeneidade das formas sociais citadinas atreladas há um tempo outro, qual seja, o da velocidade e da vida mental (Simmel, 1987) inerente às formas culturais urbanas oriundas da metrópole amazônica.

Tal como, para tomar um ônibus diariamente e nos deslocar na cidade torna-se necessário desenvolver determinadas técnicas corporais, para diariamente subir em um barco e dele descer, e se deslocar sobre as águas é necessário desenvolver técnicas diferenciadas, considerando-se a instabilidade do meio líquido.
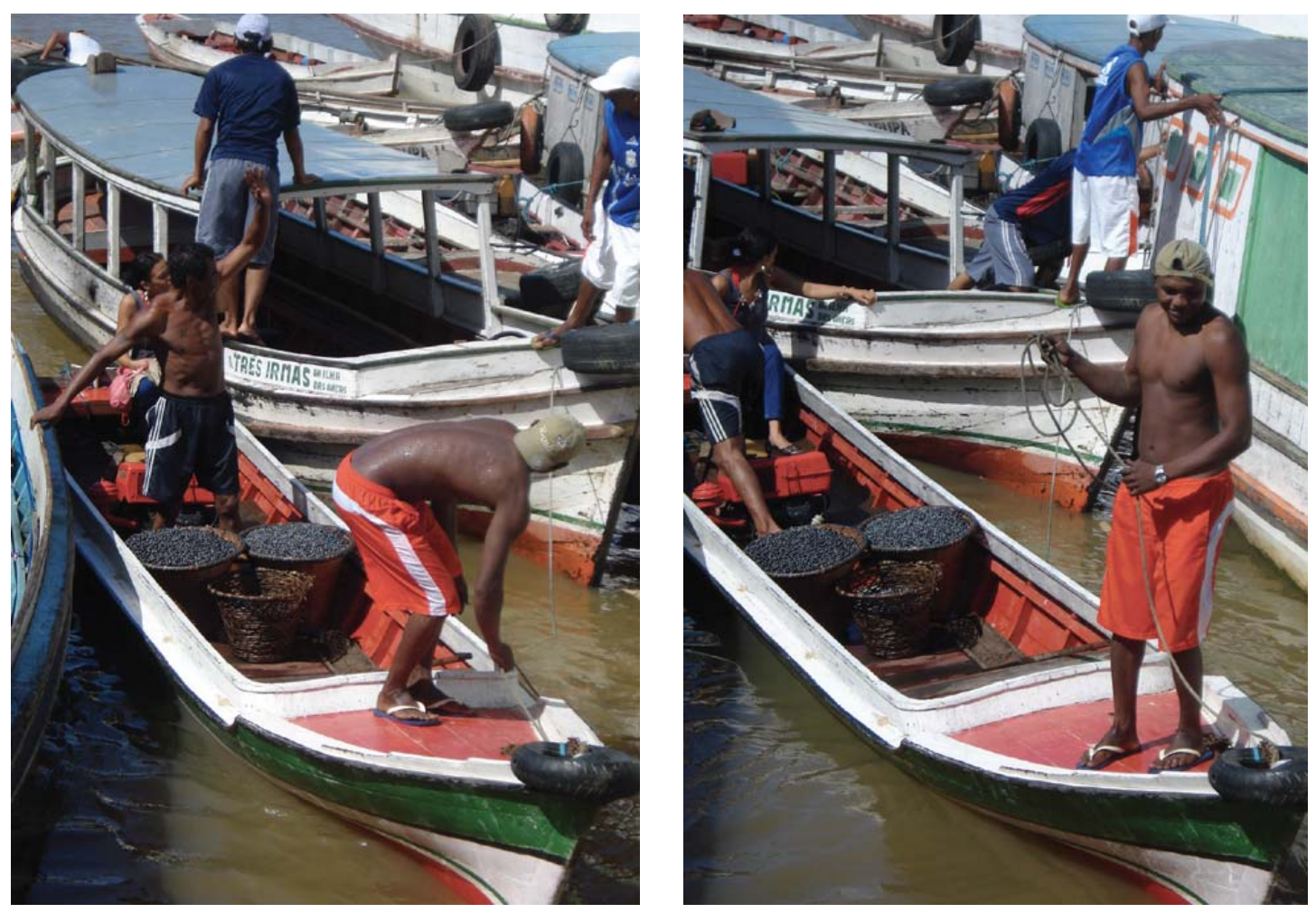

Fonte: acervo pessoal dos autores 
As práticas cotidianas comumente realizadas pelas pessoas ao se deslocar sobre os barcos posicionados próximos uns dos outros junto ao porto do Açaí - passar de um barco a outro; saltar; segurar-se e/ou apoiar-se nas embarcações; ascender ao trapiche e deslocar-se nele, entre outras - geram os pesquisadores, por exemplo, situações de temor e tensão em circunstâncias de trabalho de campo - fato também vivenciado por Arreguí (2008) para em sua pesquisa junto aos quilombolas ("as populações das selvas brasileiras") -, demandando certas técnicas e posturas pouco usuais aos habitantes do centro-interior da cidade de Belém, cuja relação com o rio não se dá no sentido de utilizá-lo como lugar de deslocamento cotidiano.

Além disso, o cálculo mental de distâncias a percorrer e as maneiras de vencer os possíveis riscos no trânsito por bordas, tetos e proas de embarcações se devem às formas sensíveis de lidar com objetos e lugares, bem como aos mapas mentais (Gell, 1985) que organizam o fluxo e a disposição dos corpos no espaço praticado, a partir da experiência acumulada. Tais situações exigem técnicas de utilização do corpo que colocam ao sujeito uma hermenêutica do meio, pressupondo decisões rápidas que engendram táticas quando o si-mesmo em um processo reflexivo define - também no corpo - as ações a realizar.

Durante um diálogo com dona Edna, moradora da ilha do Maracujá, sobre a insegurança de um dos pesquisadores ao andar sobre os barcos atracados até alcançar a embarcação que levaria ao local da pesquisa, foi possível explicar o contraste entre o incômodo dele e

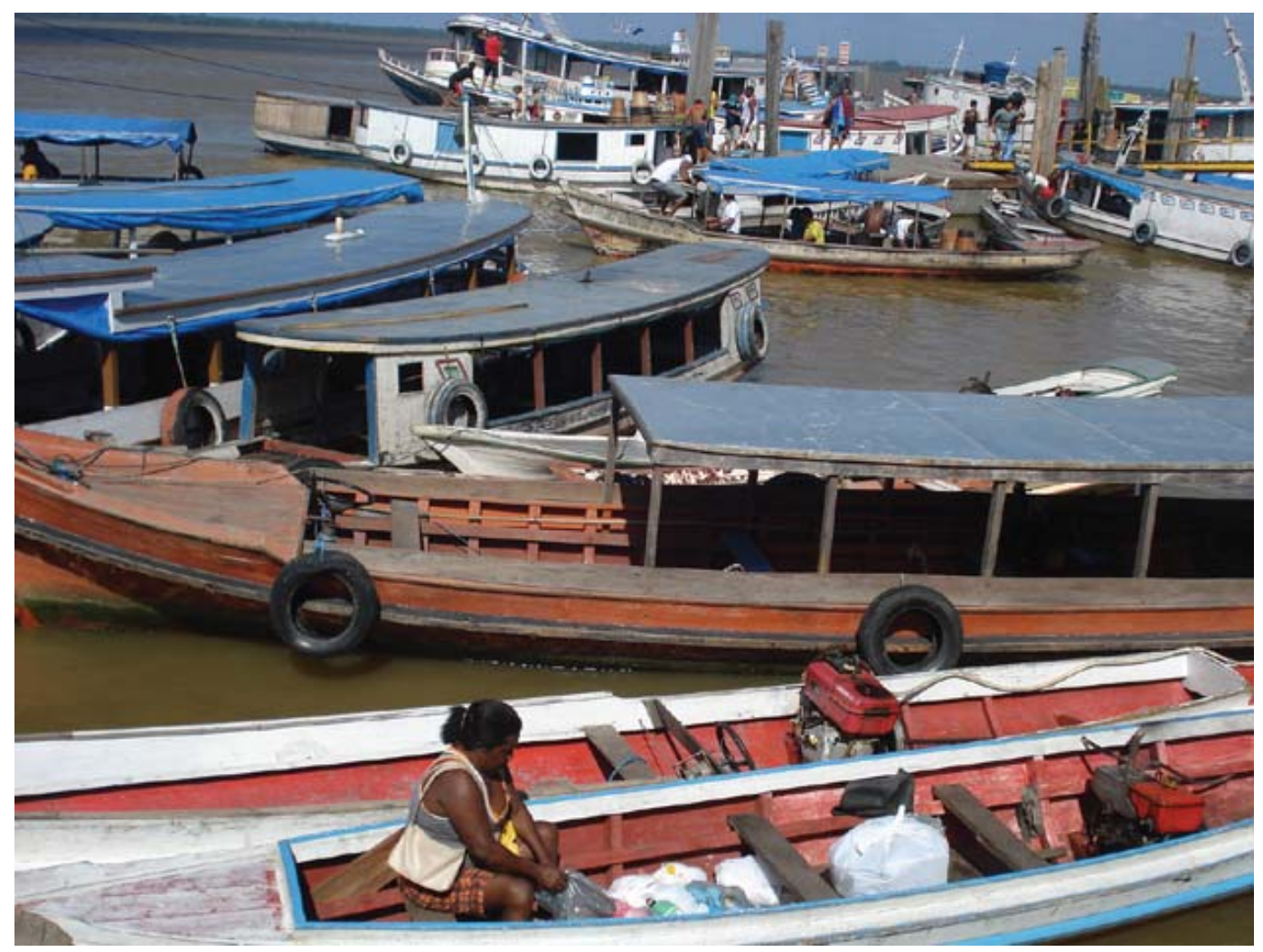

Fonte: acervo pessoal dos autores 
a destreza da senhora. Ela, que geralmente carrega sacolas plásticas com vários mantimentos por sobre os barcos atracados, afirmou: "É o costume, a gente se acostuma com esse balanço que depois nem sente!"

Nessa afirmação, dona Edna enfatiza aspectos de sua própria trajetória de vida, já que experimentou uma adaptação a outra realidade, com domínio e destreza sobre determinada situação vivida, pois, tendo nascido na ilha do Marajó, mudou-se em seguida para Belém; portanto, morou em 'terra-firme', e somente depois se transferiu para a ilha do Maracujá, tendo-se mudado do bairro do Jurunas para o local, em 2000, com a sua família. O caso de seu Abaeté também demonstra tal plasticidade.

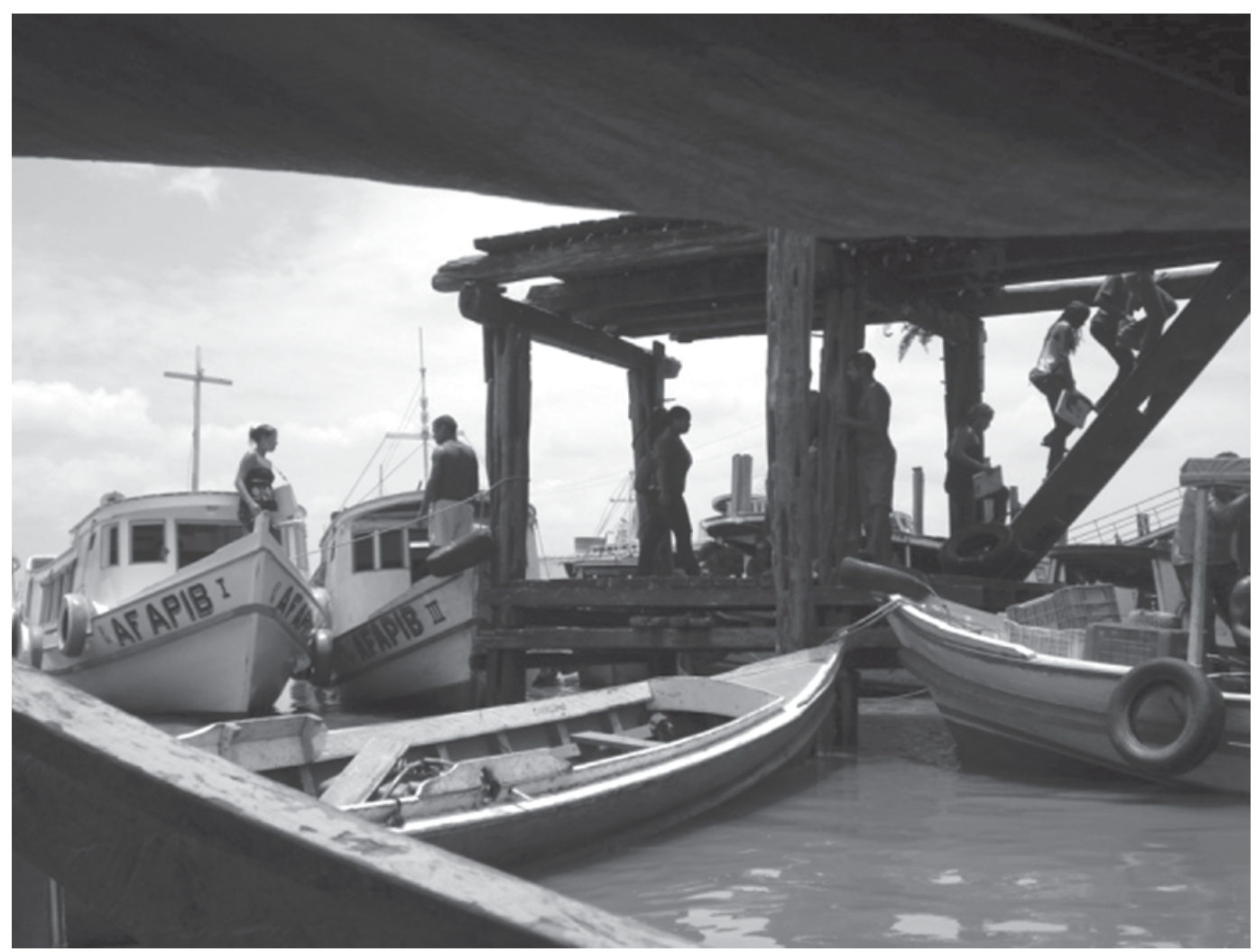

Fonte: acervo pessoal dos autores

É a possibilidade de adaptação/plasticidade humana aos novos contextos socioambientais que tem dona Jesus, moradora ainda recente da ilha do Maracujá, onde exerce a função de professora. A senhora comentaria em certa ocasião que já se acostumou a pilotar o barco da família quando há necessidade de fazê-lo - diferentemente de algumas crianças, que aprendem a pilotar as embarcações desde cedo -, ainda que demonstre certa insegurança ao pilotá-lo.

Na próxima imagem, ela aparece deslocando-se de sua residência, localizada quase na confluência do rio Pará com o furo do Benedito, até o furo do Maracujá Grande, ao sul da ilha, onde iria participar de uma reunião de pais e mestres. 

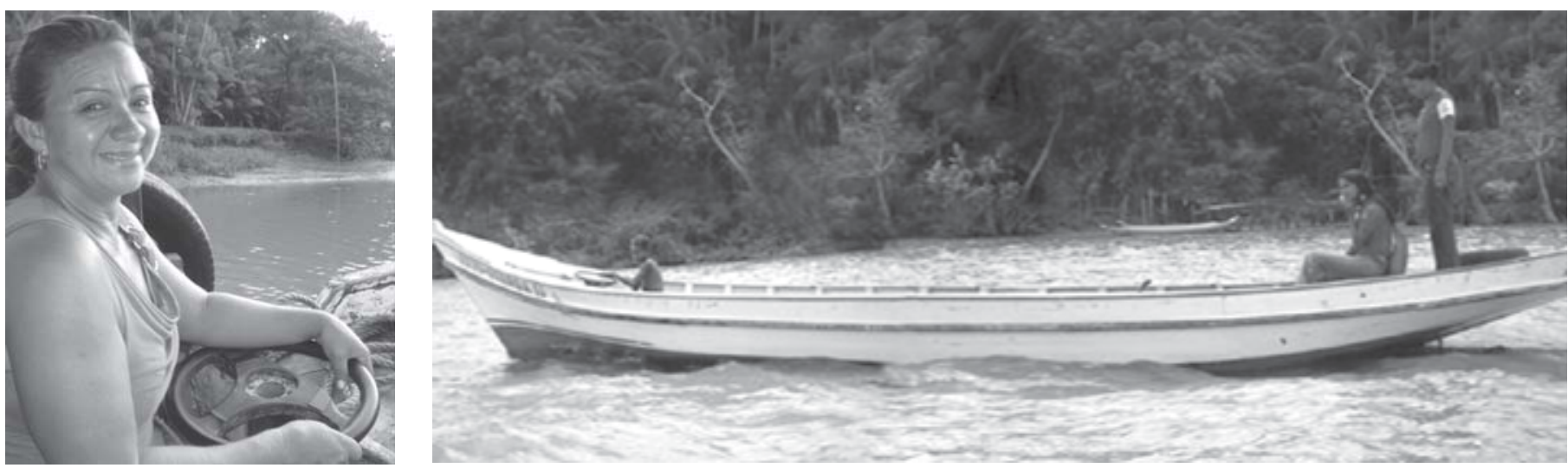

Fonte: acervo pessoal dos autores

\section{Do uso das imagens e sua importância etnográfica}

Se a mirada de uma margem à outra do rio coloca a questão das perspectivas cruzadas, evocando a imagem simmeliana da proximidade-distância entre sujeitos e pontos geográficos, das derivas e itinerâncias possíveis pelas vagas e remansos fluviais, também sugere que os nossos olhares estão situados em relação a uma fenomenologia dos gestos e das práticas cotidianas, relativas às formas sociais de interação com as águas, as beiradas e a mata que estão sendo evidenciadas nesse constante trânsito humano.

Seguindo tal fluxo de ideias, partiu-se do princípio de que os nossos olhares sobre tais bordas conformam uma 'terceira margem do rio' - para usar, seguindo um estímulo bachelardiano, uma imagem poética cara a Guimarães Rosa -, ou ainda, outra mirada que procura estabelecer nexos e "pontes"11 de intercâmbio entre essas paisagens por meio do exercício etnográfico, a fim de melhor compreendê-las. Daí a importância da simbólica das imagens para a compreensão das interações entre os corpos - seus gestos e posturas com as ambiências praticadas, sejam elas os barcos, as pontes e as beiras, de forma a captar nuanças das experiências vividas pelos ribeirinhos no seu cotidiano.

Da terceira margem do rio vislumbra-se, por intermédio do olhar sensível e atento do etnógrafo, a incessante manifestação das diferenças e das semelhanças dos ilhéus em relação à margem continental, ora aproximando, ora distanciando as margens que partilham o leito do rio Guamá.

O que o olho-câmera registra/fotografa nas paisagens são corpos ativos e altivos, corpos nutridos de uma intimidade com as ambiências, uma vez que percorrem as matas, a terra e a água com destreza de quem as conhece profundamente; corpos fortes que ocultam relações com ambientes hostis e contrastam, de certa maneira, com os corpos dos moradores da margem continental, que percorrem superfícies previsíveis, mas que, ainda assim, estão imbricados à experiência da proximidade com a selva e o rio pelo constante ir e vir entre as beiradas.

Universo de águas que se encaixa perfeitamente nas considerações de Eidorfe Moreira (1966, p.66) quando menciona que "a cidade floresceu em função da água. 'Flor das águas' 
- eis uma antonomásia que se ajustaria muito bem à capital paraense, tal a significação dos elementos hídricos na sua vida".

Partindo da perspectiva de Claudine de France (1998, p.135) sobre o exame direto das técnicas corporais para o seu registro, utilização em trabalhos acadêmicos e a sua relação com a imagem, é possível parafraseá-la e propor a seguinte indagação: o que a utilização da fotografia revela sobre o corpo e "sobre seu papel de fio condutor" das experiências sensíveis dos ribeirinhos com suas paisagens de pertença?

Diante da potência das águas, os moradores da ilha precisam frequentemente ser enquadrados - no sentido de obter a imagem - em situações de equilíbrio, seja nos barcos, nas pontes, no porto, nos açaizeiros, onde seus corpos parecem conjugar o duplo caráter de objeto transportado e instrumento de transporte, deixando transparecer, aos mais atentos, habilidades corporais que funcionam como condição sine qua non para habitar matas, margens e águas de rio.

Apesar de registros estáticos, as fotografias obtidas ao longo do trabalho de campo indicam expressões do modo de ser de uma população que habita uma ilha às margens de um rio que banha uma metrópole na Amazônia, bem como elementos importantes para a reflexão antropológica sobre o corpo e seu movimento (France, 1998). Mediante a força narrativa da imagem - vinculada à intencionalidade etnográfica dos pesquisadores - foi possível obter imagens acerca das técnicas corporais relativas às práticas cotidianas dos moradores da ilha do Maracujá que revelam saberes e fazeres (Certeau, 1994) associados a um conjunto de gestos, relacionados às formas de manejo dos ambientes pelos grupos sociais em seu devir no tempo e no espaço (Silveira, 2009).

Nas suas reflexões, Claudine de France (1998) permite estabelecer relações de proximidade entre a antropologia e o cinema, indicando a habilidade do antropólogo de colocar-se no lugar de observador particular, enfatizando uma maneira própria de ver, construída a partir de um jogo relacional entre o pesquisador [ou o cineasta] e os seus interlocutores, possibilitando, dessa maneira, o registro que resulta em uma narrativa etnográfica por imagens. Há uma intensa proximidade entre o antropólogo e a câmera, pois o antropólogo que observa e registra o que vê impregna a própria escrita antropológica de metáforas visuais como 'ver', 'observar', 'ler', para não citar outras mais específicas. Ainda assim, os registros visuais não foram absorvidos de pronto na antropologia, daí a necessidade enfática, disciplinar, de "sugerir formas pelas quais se possa olhar dentro das fotografias e através delas dentro da cultura" (Edwards, 1996, p.25), uma vez que a imagem transcende o dado.

Uma fotografia expressa o deslocamento constante no tempo e no espaço, possibilitando destacar um aspecto, "um único incidente na história", tornando visível o que era invisível, perceptível o que até então parecia despercebido. No registro fotográfico, o poder implícito de revelar, de "se apropriar do tempo e do espaço e daqueles que existem dentro dele" (Edwards, 1996, p.16) é significativo para o processo de interpretação do contexto estudado. Por outro lado, o enquadramento do fotógrafo "transforma-se em um símbolo para o todo e induz o espectador a admitir o específico como generalidade, tornando-se um emblema de verdades mais vastas" (p.17), possibilitando modos ver e, portanto, hermenêuticas.

Assim como a antropologia ocupa-se em observar os aspectos estruturais significativos de uma cultura, em registrar os fragmentos trazidos pelos informantes que depois serão 
compactados em uma narrativa unificadora da cultura, mostrando que o trabalho final surge primeiro da síntese e depois da generalização, também na fotografia "o momento específico torna-se representativo do todo e do geral" (Edwards, 1996, p.17).

Esse aspecto revelador da fotografia, da imagem fixa, é destacado neste artigo. As fotos dos moradores da ilha do Maracujá revelam aspectos cotidianos de uma corporeidade sempre à mostra, um corpo pulsante, pois "na Amazônia, a verdadeira 'obra de arte', o sinal de identidade, é o corpo" (Arreguí, 2008, p.32); o corpo projeta-se e participa nas paisagens com uma simbólica dinâmica entre os povos da selva amazônica, sejam ribeirinhos ou não.

Essas imagens tendem a despertar na 'imaginação criadora' do antropólogo em campo uma série de ponderações acerca da simbólica relativa a uma corporeidade caboclo-ribeirinha. Sendo assim, o olhar mediado pelo uso da câmera fotográfica chama a atenção para aspectos relativos a uma fenomenologia do corpo no contexto amazônico, conjugando corporeidade e espacialidade. Portanto, a partir de uma etnografia por imagens é possível compreender aspectos relevantes em relação ao fluxo ilha-metrópole e vice-versa, bem como as relações que a partir dele se estabelecem.

Alfredo Bosi (1988, p.79) chama a atenção para o fato de que existe uma relatividade e uma corporeidade presentes no olhar: a simbólica do olhar está sempre situada e emerge a partir de uma visada; por outro lado, o olhar é sempre oriundo da experiência corporal, ambos de caráter sensível. Há no olhar uma corporeidade que lhe é imanente, mas nem por isso irracional; pelo contrário, é uma corporeidade munida de razões profundas "que enformam o olhar do homem em situação" e desmontam a crença num olhar isento, apriorístico; uma prova disso são as "várias imagens com que a antropologia popular descreve modos-de-ser, mediante modos-de-olhar [e que] relativizam toda a noção a priori de olhar como espelho de uma percepção isenta".

A perspectiva do autor aproxima-se da ideia de uma 'razão sensível' apontada por Maffesoli (2005) quando intenta mostrar as tensões entre cosmovisões que separam a razão da sensibilidade. Nesses termos, a imagem, para a pesquisa em questão, é uma forma de captar o 'sentir coletivo' ribeirinho, uma vez que a imagem seria um importante 'vetor de comunhão'. Esse exercício complexo coloca em jogo a dimensão pessoal e metodológica do observador em campo, o desdobrar-se ora em sujeito, ora em objeto de um olhar situado na interação com o Outro.

Para Alfredo Bosi (1988, p.79), há que "descobrir as relações tantas vezes obscuras, entre o ponto de vista e os processos intra e intersubjetivos nos quais o olhar se forma e se move". Para o observador situado à terceira margem do rio, não é diferente. As imagens compõem o processo hermenêutico revelando o corpo como uma forma de narrativa, capaz de expressar a simbólica presente nas práticas e posturas do Outro em relação ao seu mundo. Afinal, as ligações entre o corpo, o olhar e a produção de conhecimento são profundas. Para MerleauPonty, ver é sempre ver através de um determinado corpo, pois é através do olhar que primeiro interrogamos as coisas; o corpo deve ser compreendido como um sistema voltado para conhecer o mundo, e não custa dizer que é o corpo que conhece.

O olhar que capta as imagens dos moradores da ilha na sua vida diária é o olhar que, situado numa perspectiva hermenêutica, utiliza o registro visual e textual para produzir 
uma narrativa mais reflexiva do que descritiva, mais introdutória do que conclusiva, trazendo com isso mais interrogações do que verdades; trata-se, portanto, de uma narrativa em aberto.

\section{NOTAS}

${ }^{1}$ Podemos destacar o livro organizado por Ondina Fachel Leal, intitulado Corpo e significado: ensaios de antropologia social (1995) e os trabalhos de José Carlos Rodrigues, especialmente Tabu do corpo (2006b); Tabu da morte (2006a), entre outras obras.

2 Este artigo não se propõe a discutir a problemática relativa ao uso da palavra 'caboclo'. Para tanto, ver, a partir de diferentes abordagens, os seguintes autores: Galvão (1976); Magalhães Lima (1999); Maués (1990), Motta-Maués (1993); Pace (2006); Rodrigues (2006) e Wagley (1988), entre outros. Mark Harris (1998a) tanto usa caboclo como ribeirinho (riverine).

${ }^{3}$ Furo é um trecho de água passível de ser navegado, servindo de canal de comunicação entre um rio e seus afluentes.

${ }^{4} \mathrm{O}$ arquipélago que circunda Belém é composto por aproximadamente 39 ilhas - sendo 13 pertencentes ao distrito administrativo do Mosqueiro -, as quais, juntamente com os bairros que formam a cidade, passam a compor sua área metropolitana distribuída em distritos administrativos de acordo com a lei 7682/94, de 5 de janeiro de 1994, da Câmara Municipal de Belém.

${ }^{5}$ A fala de seu Abaeté - feirante no porto e um dos interlocutores da pesquisa - que aparece no fascículo 7 da Nova Cartografia Social da Amazônia (2008), é ilustrativa: "A vida do porto, a vida no porto pra mim, pros feirantes, pros ribeirinhos é a vida, é a nossa vida! Sem o porto nós não sobrevivemos".

${ }^{6}$ Recipientes confeccionados com cipó de guarumã trançado, onde são acondicionados os frutos do açaizeiro. Também funcionam como medida de peso, sendo frequentemente chamados de paneiros no contexto amazônico.

${ }^{7}$ De acordo com Wacquant (2003, p.14-15) "Contrariamente ao estruturalismo, portanto, a teoria do habitus reconhece que os agentes fazem o mundo social ativamente ao empenharem instrumentos corporificados de construção cognitiva; mas ela também afirma, contra o construtivismo, que tais instrumentos foram eles próprios produzidos pelo mundo social (Bourdieu, 2000). O habitus fornece ao mesmo tempo princípios de sociação (sociation) e individuação ... Por ser ao mesmo tempo estruturado (por meios sociais do passado) e estruturante (das representações e ações presentes), o habitus opera tal como o 'princípio não escolhido de todas as escolhas', guiando ações que assumem o caráter sistemático de estratégias, ainda que não sejam produtos de intenção estratégica e que objetivamente sejam 'orquestradas sem ser produtos da atividade organizadora de um maestro (Bourdieu, 1990, p.256)".

${ }^{8}$ Localizada ao sul de Belém, a uma distância de aproximadamente $3 \mathrm{~km}$ de sua porção mais setentrional em relação à margem mais próxima de Belém, de acordo com os dados fornecidos pela Companhia de Desenvolvimento e Administração da Área Metropolitana de Belém, em 2009.

${ }^{9}$ André Leroi-Gourhan (1987, p.91-92) afirma o seguinte sobre o equilíbrio: "Se a armação esquelética não é perceptível no estado normal, já o invólucro muscular é o centro de impressões importantes, podendo considerar-se o dispositivo osteomuscular, já não como um utensílio, mas como um instrumento de inserção na existência. Convém deixar de parte, enquanto operação intelectual, a integração dos movimentos que se opera no córtex cerebral motor; em contrapartida, podemos notar a relação paleontológica existente entre o ouvido interno e o aparelho osteomuscular no respeitante ao equilíbrio do indivíduo relativamente ao meio, nas percepções espaciais imediatas, e na organização dos movimentos. O peso do corpo é sentido pelos músculos, combinando-se com o equilíbrio espacial para manter o homem preso ao seu universo concreto ... Tanto para o animal como para o homem, o equilíbrio reside na ação coordenada dos órgãos e dos músculos, de acordo com o desenrolar de cadeias rítmicas de diferentes amplitudes, imbricadas umas nas outras segundo uma ordem regular". Poderíamos fazer referência à noção de uma biomecânica do corpo quilombola no contexto amazônico ("a biomecânica observada nas selvas do Brasil"), como aparece em Arreguí (2008, p.25).

${ }^{10}$ Instrumento usado nos pés do escalador de algumas palmeiras, normalmente confeccionado com folhas do açaizeiro ou outra palmeira, que facilita a subida no estipe da planta (Embrapa.., 2006).

${ }^{11}$ Aqui temos em mente a figura do estrangeiro e a imagem da ponte, evocadas por Georg Simmel (1983, 1996a). 


\section{REFERÊNCIAS}

ANGOTTI-SALGUEIRO, Heliana.

A construção de representações nacionais: os desenhos de Percy Lau na Revista Brasileira de Geografia e outras "visões iconográficas" do Brasil moderno. Anais do Museu Paulista. São Paulo, v.13, n.2, p.21-72. 2005.

ARREGUí, Aníbal García.

La tecnologia en el cuerpo: biomecánica de los quilombolas en dos selvas brasileñas. (con)textos, Barcelona, n.1, p.23-40. 2008.

AUGÉ, Marc.

Não lugares: introdução a uma antropologia da supermodernidade. Campinas: Papirus. 1994.

BACHELARD, Gaston.

A Terra e os devaneios da vontade: ensaio sobre a imaginação das forças. São Paulo: Martins Fontes. 1.ed., 1948. 1991.

BACHELARD, Gaston.

A Terra e os devaneios do repouso: ensaios sobre as imagens da intimidade. São Paulo: Martins Fontes. 1.ed., 1948. 1990.

BARBA, Eugenio; SAVARESE, Nicolas.

$A$ arte secreta do ator: dicionário de antropologia teatral. Campinas: Editora Unicamp. 1995.

BASTIDE, Roger.

Técnicas de repouso e de relaxamento (estudo transcultural). In: Bastide, Roger. Sociologia. São Paulo: Ática. p.88-112. (Org., Maria Isaura Pereira de Queiroz). 1983.

BOLTANSKI, Luc.

As classes sociais e o corpo. Rio de Janeiro: Graal. 1984.

BOSI, Alfredo.

Fenomenologia do olhar. In: Novaes, Adauto (Org.). O olhar. São Paulo: Companhia das Letras. 1988.

BOURDIEU, Pierre.

O poder simbólico. Rio de Janeiro: Bertrand Brasil. 1998.

BOURDIEU, Pierre.

Esboço de uma teoria da prática. In: Ortiz, Renato (Org.). Pierre Bourdieu. São Paulo: Ática. p. 46-81. 1994.

BOURDIEU, Pierre.

Remarques provisoires sur la perception sociale du corps. Actes de la recherche en sciences sociales, Paris, v.1, n.14, p.51-54, 1977.

CERTEAU, Michel de.

A invenção do cotidiano: artes de fazer. v.1. Petropóolis: Vozes. 1994.
CSORDAS, Thomas.

Corpo/significado/cura. Porto Alegre: Editora da UFRGS. 2008.

DIEGUES, Antonio Carlos.

As ilhas e arquipélagos tropicais brasileiros: práticas sociais e simbólicas. In: Diegues, Antonio Carlos (Org.). Ilhas e sociedades insulares. São Paulo: Nupaub; USP. p.3-36. 1997.

DOUGLAS, Mary.

Pureza e perigo. São Paulo: Perspectiva. 1.ed., 1966. 1976.

DURAND, Gilbert.

As estruturas antropológicas do imaginário. Lisboa: Presença. 1989.

EDWARDS, Elizabeth.

Antropologia e fotografia. Cadernos de Antropologia e Imagem, Rio de Janeiro, n.2, p.11-28. 1996.

ELIAS, Norbert.

A sociedade dos indivíduos. Rio de Janeiro: Jorge Zahar. 1994.

EMBRAPA...

Embrapa Amazônia Oriental. Sistema de produção do açaí. Sistemas de produção, n.4. Disponível em: http://sistemasdeproducao. cnptia.embrapa.br/FontesHTML/Acai/ SistemaProducaoAcai_2ed/index.htm. Acesso em: 20 set. 2011. Dez. 2006.

FRANCE, Claudine de.

Cinema e antropologia. Campinas: Editora da Unicamp. 1998.

GALVÃO, Eduardo.

Encontro de sociedades: índios e brancos no Brasil. Rio de Janeiro: Paz e Terra, 1.ed., 1954. 1976.

GELL, Alfred.

How to read a map: remarks on the practical logic of navigation. Man, Londres, v.20, n.2, p.271-286. 1985.

HARRIS, Mark.

'What it means to be caboclo': some critical notes on the construction of Amazonian caboclo society as an anthropological object. Critique of Anthropology, s.1., v.18, n.1, p.83-95. 1998a.

HARRIS, Mark.

The rhythm of life Amazon foodplain: seasonality and sociality in a riverine village. Journal of the Royal Anthropological Institute, Londres, n.4, p.65-82. 1998b. 
INGOLD, Tim.

The perception of the environement: essays on livelihood, dwelling and skill. Londres: Routledge. 2000.

LE BRETON, David.

A sociologia do corpo. Rio de Janeiro: Vozes. 2006.

LEAL, Ondina Fachel (Org,).

Corpo e significado: ensaios de antropologia social. Porto Alegre: Editora da UFRGS. 1995.

LEROI-GOURHAN, André.

O gesto e a palavra: técnica e linguagem. v.1. Lisboa: Perspectiva do Homem; Edições 70. 1.ed., 1964. 1990.

LEROI-GOURHAN, André.

O gesto e a palavra: memória e ritmos. v. 2. Lisboa: Edições 70. 1.ed., 1965. 1987.

MAFFESOLI, Michel.

Elogio da razão. Petrópolis: Vozes. 2005.

MAFFESOLI, Michel.

O poder dos espaços de representação. Tempo Brasileiro, Rio de Janeiro, n.116, p.59-70. 1994.

MAFFESOLI, Michel.

O tempo das tribos: o declínio do individualismo nas sociedades de massa. Rio de Janeiro:

Forense-Universitária. 1987.

MAGALHÃES LIMA, Deborah.

A construção histórica do termo caboclo: sobre estruturas e representações sociais no meio rural amazônico. Novos Cadernos NAEA, Belém, v.2, n.2, p.5-32. 1999.

MAUÉS, Heraldo Raimundo.

A ilha encantada: medicina e xamanismo numa comunidade de pescadores. Belém: Edufpa. 1990.

MAUSS, Marcel.

As técnicas corporais. In: Mauss, Marcel.

Sociologia e antropologia. São Paulo: EPU. p.211-233. 1974.

MERLEAU-PONTY, Maurice.

Fenomenologia da percepção. Rio de Janeiro: Freitas Bastos. 1971.

MOREIRA, Eidorfe.

Belém e sua expressão geográfica. Belém: Imprensa Universitária, 1966.

MOTTA-MAUÉS, Maria Angélica.

"Trabalhadeiras" \& "camarados": relações de gênero, simbolismo e ritualização numa comunidade amazônica. Belém: Edufpa. 1993.

NEVES, Delma Pessanha.

Os ribeirinhos-agricultores de várzea: formas de enquadramento institucional. Novos Cadernos NAEA, Belém, v.1, n.12, p. 67-92. 2009.
NOVA CARTOGRAFIA...

Nova Cartografia Social da Amazônia. Série

"Movimentos sociais e conflitos nas cidades da Amazônia". Fascículo 8. Ribeirinhos das ilhas de Belém. Disponível em: http://www.nova cartografiasocial.com/index.php?option=com phocadownload\&view=category\&id=1\&Itemid=64 . Acesso em: 20 set. 2011. s.d.

NOVA CARTOGRAFIA..

Nova Cartografia Social da Amazônia. Série "Movimentos sociais e conflitos nas cidades da Amazônia". Fascículo 7. Feirantes e ribeirinhos dos portos públicos de Belém. Disponível em: http://www.novacartografiasocial.com/ index.php?option=com_phoca download\&view= category\&id=1\&Itemid $=64$. Acesso em: 20 set. 2011. Fev. 2008.

PACE, Richard.

Abuso científico do termo 'caboclo'? Dúvidas de representação e autoridade. Boletim do Museu Paraense Emílio Goeldi, Ciências Humanas, Belém, v.1, n.3, p.79-92. 2006.

RODRIGUES, Carmen Izabel.

Caboclos na Amazônia: a identidade na diferença. Novos Cadernos NAEA, Belém, v.1, n.9, p.119-130. 2006.

RODRIGUES, José Carlos.

Tabu da morte. Rio de Janeiro: Editora Fiocruz. 2006 .

RODRIGUES, José Carlos.

Tabu do corpo. Rio de Janeiro: Editora Fiocruz. 2006b.

SANSOT, Pierre.

Les formes sensibles de la vie sociale. Paris: PUF. 1986.

SEEGER, Anthony; DAMATTA, Roberto; VIVEIROS DE CASTRO, Eduardo. A construção da pessoa nas sociedades indígenas brasileiras. In: Pacheco de Oliveira Filho, J. (Org.). Sociedades indígenas e indigenismo no Brasil. Rio de Janeiro: UFRJ; Marco Zero. p.11-39. 1987.

SILVEIRA, Flávio Leonel Abreu da. A paisagem como fenômeno complexo, reflexões sobre um tema interdisciplinar. In: Silveira, Flávio L. A. da; Cancela, Cristina D. Paisagem e cultura: dinâmica do patrimônio e da memória na atualidade. Belém: Edufpa, p.71-83. 2009.

SIMMEL, Georg.

A ponte e a porta. Política \& Trabalho, João Pessoa, n.12, p.10-14. 1996a.

SIMMEL, Georg.

A filosofia da paisagem. Política \& Trabalho, João Pessoa, n.12, p.15-24. 1996b. 
SIMMEL, Georg.

A metrópole e a vida mental. In: Velho, Otávio (Org.). O fenômeno urbano. Rio de Janeiro:

Guanabara. 1987.

SIMMEL, Georg.

Sociologia. São Paulo: Ática. (Org., Evaristo de Moraes Filho). 1983.

SUBINDO NO AÇAIZEIRO.

1 fot. color. Disponível em: http://travel. webshots.com/photo/10122637620277

05730YURwwPxoPc. Acesso em: 20 set. 2011. 2011.
VIVEIROS DE CASTRO, Eduardo.

A fabricação do corpo na sociedade xinguana. In: Pacheco de Oliveira Filho, J. (Org.).

Sociedades indígenas e indigenismo no Brasil. Rio de Janeiro: UFRJ; Marco Zero. p.31-39. 1987.

WACQUANT, LoÏc.

Mapeando o habitus. Habitus, Goiânia, v.1, n.1, p.11-18. 2003.

WAGLEY, Charles.

Uma comunidade amazônica: estudo do homem nos trópicos. Belo Horizonte: Itatiaia; São Paulo: Edusp, 1.ed., 1953. 1988. 